\title{
Local Identity or Economic Benefits? The Municipal Splits in the Czech Republic
}

\begin{abstract}
This paper studies 38 splits that occurred between 1995 and 2020 in the Czech Republic. Although the initial splits, that took place during the time of democratic transition, were driven by perceived local identity and the historical memory of being a former independent municipality, the splits after 1995 were predominantly driven by economic factors, be it objective underinvestment and a perceived grievance that the mother municipality was not taking care of its fringe parts. In all cases, the mother municipality had failed to communicate with the initiator of a referendum. However, if the central municipality invested in its parts and its political leaders communicated with its citizens, the municipality did not lose its part despites the attempts of secessionist leaders.
\end{abstract}

Keywords

Municipal splits • economy of scale • the Czech Republic • municipal fragmentation $\cdot$ territorial reform $\bullet$ local competition

(C) University of Warsaw - Faculty of Geography and Regional Studies

\author{
Jakub Lysek (C) \\ Department of Politics and European Studies, \\ Palacký University Olomouc, Czech Republic \\ e-mail: jakub.lysek@gmail.com \\ Received: 23 April 2020 \\ Accepted: 3 November 2020
}

Introduction

While in Western Europe amalgamation reform is fiercely discussed, in some Eastern European countries, including the Czech Republic, it is nearly taboo. There, rapid growth in the number of municipalities occurred after the regime change in 1989 (Illner 2011). By 1994, the total number of municipalities had stabilized and the number has remained much the same since then. Minor changes are due to the extinction of several depopulated municipalities or to the transformation of former military areas into renewed municipalities. Yet significant changes happened because of municipal splits or divorces. In total, there have been 38 splits of municipal parts from mother municipalities (1995-2020). The time frame was chosen because it excludes the municipal splits in the specific transition period and focuses only on the time after which the municipal structure had stabilized. Additionally, it corresponds to the chosen timeframe of other country cases in this volume. The aim of the study is thus to answer the research question of why those municipalities split, and whether a common pattern across those municipalities may be identified.

Municipal splits in the Czech Republic have remained largely understudied. Two studies close to the topic discuss splits, but only indirectly (Vajdová et al. 2006; Bernard \& Kostelecký 2010). Bernard \& Kostelecký (2010) analyse and compare the socioeconomic development of small communities that have their own local government (traditional or newly created municipalities) and communities that form part of a bigger municipality and do not therefore have their own local government, but not the municipal splits per se. One reason might be that the municipal structure is immensely fragmented. With 6,258 municipalities in 2020 , the 38 splits do not seem to be worthy of study, especially when the last secession of two city parts of one MoravianWallachian municipality occurred quite a long time ago, in 2012, and due to a specific reason - in order to close a grammar school in one of the parts. Reading the information on splits in daily local news, one might come to the hasty conclusion that municipal divorce is due to specific local reasons a foreign observer could not understand and that it is not worthy of being systematically studied. Nevertheless, when we look at municipal splits from a comparative perspective, common patterns can be observed.

First, most of the split municipalities were geographically detached from the mother municipality and were unproportionally small in comparison. Second, the splits occurred predominantly in Moravia, while in Bohemian regions, splits were rare. This is because of the specific local culture and identity of municipalities in Moravia (see Illner 1999, p.89). Here, citizens feel strong attachment to their municipality and are very active in organizing local cultural events. While this might be interesting for a Czech reader, it is not a satisfactory answer to the broader community of local government researchers. We have to look for broad generalizable explanations.

There have been several explanations of municipal splits proposed in the academic literature (Erlingsson 2005; Tanguay \& Wihry 2008; Dollery et al. 2011; Lima \& Neto 2018; Swianiewicz \& Łukomska 2019). These include the economic reasons, the culture, and the agency-based approach that focuses on political actors and local community leaders. Those factors can be subsumed into two types: (1) the environment (or context) and (2) the actors of the policy arena (see Swianiewicz 2021 in this volume). However, they are not mutually exclusive as economic and cultural reasons can motivate political actors to act. These factors also serve as opportunity structures or contexts within which the local leaders are motivated to act. Furthermore, we cannot expect that in the case of the Czech Republic there is a single explanation. Rather, the splits result from multiple factors. Yet from the collected data, it seems that the dominant explanation favours economic reasons, 


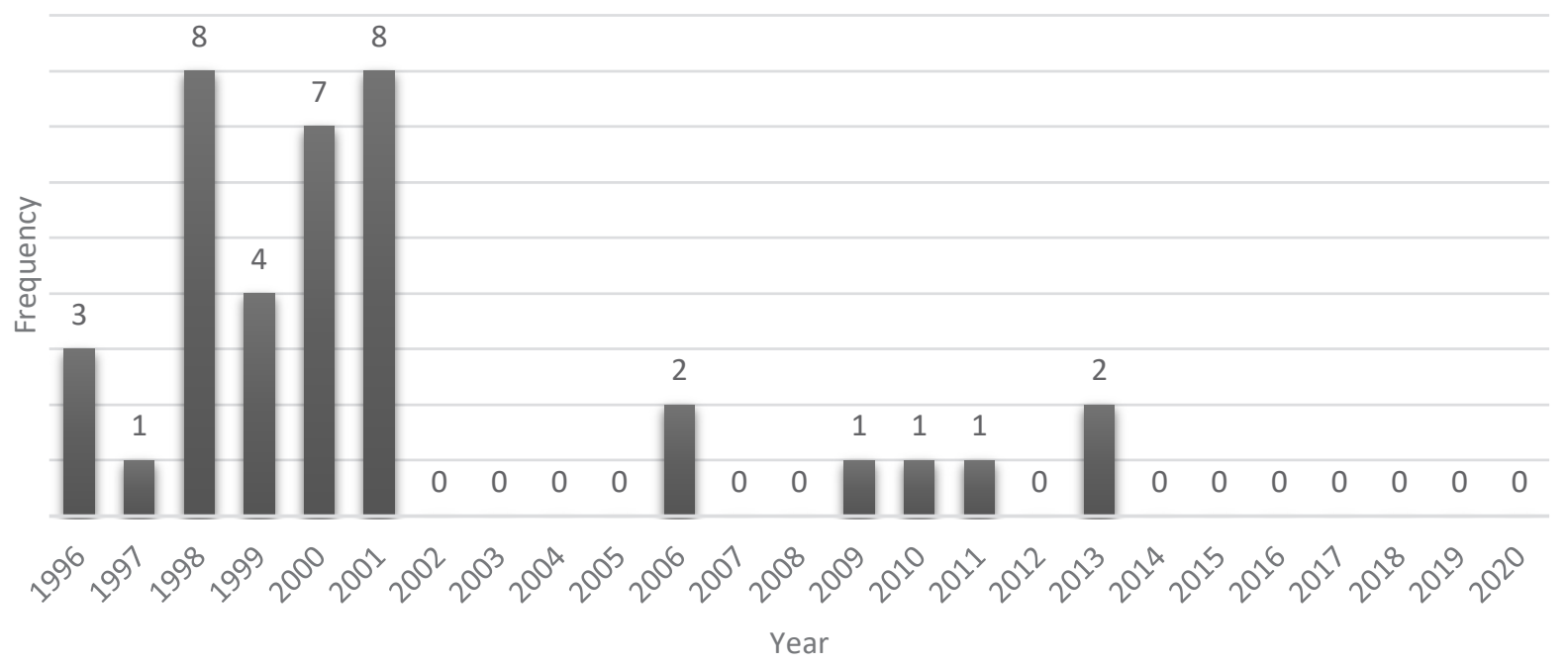

Figure 1. Timing of municipal divorces in the Czech Republic (1995-2020) Source: Czech Statistical Office.

while local culture and identity play a minor role although that had been the dominant explanation in the early 1990s.

This paper is structured as follows. First, the context of the Czech local government system and the procedural and formal rules of the secession of municipalities is explained. In the subsequent analytical section, the factors explaining the 38 splits are examined. After that, the consequences and impacts of splits on the newly established municipalities, as well as on their mother municipalities, are discussed. The last section concludes and proposes policy implications.

Historical context of municipal divorces in the Czech Republic Just after the regime change, there were virtually no obstacles for municipalities to divorce from their former central municipality (the Czech term středisková obec), which was the product of the socialist amalgamation reforms in the early 1970s (Musil 2001; Hudečková \& Pitterling 2009). Fragmentation was seen as a democratic reform in the early stage of the Czech transition (Campbell \& Coulson 2008; Illner 2011). Therefore, the Municipal Act did not stipulate any requirements for the newly created municipalities regarding a minimum population or any other thresholds. Since 1992, a local referendum must be held in the municipal part that is pursuing a split from the municipality. From 1994, The Municipal Election Act stipulated that the newly established municipality must have at least 300 inhabitants. Although the country has not experienced a dramatic number of splits in the period after 1994, the new Municipal Act of 2000 (still in force) further tightens the rules for municipal splits. It was the last chance for small municipalities, that had not done so already in the early 90 s, to split. Legislatures intended to prevent further fragmentation of the municipal structure (IIIner 2011; Bernard \& Kostelecký 2010).

At present, a new municipality may by constituted by separating part of the municipality from the existing municipality under several conditions. First, the part of the municipality wishing to separate must have a separate cadastral territory adjacent to at least two municipalities, or one municipality and a bordering state, and it must form a coherent territorial unit. Second, after separation, the new municipality must have at least 1,000 citizens. The remaining part of the municipality, after the separation of one of its parts, must meet the first two conditions. Third, and most importantly, the citizens living in the part of the municipality that wants to separate must consent via a local referendum. A self-proclaimed citizen committee initiating a referendum must create a petition and collect signatures from $30 \%$ of the population. ${ }^{1} \mathrm{~A}$ referendum is valid if a majority of registered voters in the municipal part vote for the split proposal. To put it differently, if all the citizens voted for the split, the turnout must be at least $50 \%$. This is a far stricter condition than for the general local referendum. In the case of a general referendum, the turnout requirement is $35 \%$ and for a proposal at least $25 \%$ of all the registered voters must vote. The separation of a part of the municipality is then formally authorized by the regional authority if all the conditions required by law are met.

Since 1995, which is the starting point of this study, there have been 38 splits. The dynamics have not been equal though. After 2001 (see Figure 1), we see a decline in the number of split municipalities due to the population requirement. The changes in legislation directly affected the number of splits in the Czech Republic. Before 2001, out of 31 splits, only two would have fulfilled the population requirement for a divorce stipulated by the new Municipal Act.

The first two splits under the new Municipal Act occurred in 2006 (the referendums were held in 2004). Within two years, there was legal uncertainty and procedures for the splits were not defined or settled. The first split, the municipality of Ladná, even consulted the Ministry of the Interior and successfully proposed an amendment to the Municipal Act that made it clear that secessions would always take effect in the year following the referendum (1 January). Before that, the establishment of the new part was not effective until the beginning of the calendar year following elections to municipal councils. In extreme cases, this could take four years if the referendum was held immediately after municipal elections. Furthermore, the Municipal Act does not stipulate economic and property terms of divisions. Therefore, many legal disputes had to be decided in court (e.g. a property dispute between Bohuslavice and Slavičin was ruled out by the Czech Constitutional Court); some are still ongoing.

If the population is under 3,$000 ; 20 \%$ if under 20,$000 ; 10 \%$ if under 200,$000 ; 6 \%$ if over 200,000 . 
Why do municipalities split? Theory, and the Czech context

The current literature on municipal splits is rather limited as opposed to literature on municipal amalgamation. There are two studies (Erlingsson 2005; Brink 2004) from Sweden, and Canadian (Tanguay \& Wihry 2008) and Australian (Tanguay \& Wihry 2008) studies. Regarding the region of post-communist Europe, most of the studies are focused on Poland (see Gendźwiłł et al. 2020; Swianiewicz et al. 2018). The literature divides the general factors connected to splits or that increase the likelihood of municipal secession into (1) cultural factors, (2) economic factors, and (3) political ones. All are described in detail by Swianiewicz (2021; in this volume). In this section, the structural factors that are specifically important for the Czech context such as the geographic context and municipality size are also discussed. However, both the above factors are indirectly linked to cultural or economic claims.

All the municipalities in the Czech Republic have the same scope of independent powers, although they differ in terms of state delegated powers (see IIIner 2011) as there are municipalities with extended scope $(\mathrm{N}=205)$. The municipal council is directly elected using the proportional single district electoral system. The council elects, among its members, a mayor and municipal board members (yet, in one fifth of municipalities, the board consists of a mayor only, who presides over it; see Ryšavý \& Bernard 2013). The most important revenue source is tax revenues (approximately $58 \%$ of total revenues in 2020; Ministry of Finance 2020), which are fixed by a shared tax formula that takes the municipal size, cadastral size and other criteria into account. The other sources are direct payments (state or EU funds) and fees. Generally, the institutional setting seems to be favourable for municipal divorces in the Czech Republic.

\section{Cultural factors and geographic context}

Cultural factors were the dominant force for the initial split of almost 2,000 municipalities in the first two years after the regime change (see Illner 2011). This was a reaction to forced amalgamation in the 1970s and 1980s (IIIner 2003). There was what Erlingsson (2005) calls the feeling that 'the borders were inappropriately drawn' in his study on municipal splits. A large number of municipalities formed consisted of a dominant 'capital' and much smaller 'satellite' municipalities or, more precisely, settlements without their own local government. This was and partly still is a prevailing characteristic of many Czech municipalities. There are approximately 2.5 settlements per municipality (Illner 2006). Typically, those settlements have retained their historical name, are distant to the capital, and form separate and coherent populated units, yet are merged with the mother municipality for administrative purposes (approx. 2,429; see Bernard \& Kostelecký 2010). We can rightly assume that cultural factors are still important predictors of seceded municipalities. Moreover, the geographic context of a municipality is indirectly related to the culture and identity of the municipal part. Accordingly, the more distant the part from the mother municipality, the more likely its own culture is retained. In distant municipal parts, citizens are aware of historical traditions and remain culturally distinct from the mother municipality. Conversely, if the part is an inherent part of a municipal capital, we can expect that the citizens will not develop strong separatist tendencies based on cultural factors.

\section{Economic reasons}

Several theoretical propositions concerning economic factors and their effects on municipal splits have been proposed in academic literature. First, richer parts want to split from poorer parts. This may apply both to the central municipality as well as to its parts. A study of Swedish secessions demonstrates that the richer parts seek to split and indicate economic reasons as the dominant explanation for the municipal split (Brink 2004; also, Erlingsson 2005). Second, the opposite situation might also theoretically occur when the richer centre wishes to separate from its poor parts (e.g. Gendźwiłł et al. 2020).

Although being hypothetically richer than the central municipality might be the motive for a split, a more important argument in the Czech context is that the municipal parts have no power over the municipal budget, regardless of their wealth. Therefore, discussion on whether to trigger a referendum on secession usually does not revolve around the question of whether the richer part wishes to separate from a poorer centre municipality or otherwise. The discussion centres on the amount of money the central municipality invests into the city part as opposed to the overall budget the part would have gained if it had been a separate unit. This is due to the fact that the municipal budget income is determined by an exact formula (RUD - Rozpočtové určení daní), which gives quite an accurate estimate of the municipal budget that an independent municipality could dispose of. The tax income base is calculated according to the population of a municipality exclusively, and it is practically unaffected by private companies (legal entities) sited on the part's territory (Local Finance Act 243/2000). ${ }^{2}$ Generally speaking, larger municipalities get disproportionately more money. And for the mother municipality, losing a part always means a loss in revenue. Although the municipal budget income may be increased by house property taxes and local fees (under the discretion of a municipality), these are not major sources of income for the municipal budget; the RUD is. Otherwise, the situation could have been different. This has been documented in Poland where a central town felt exploited by the more numerous surrounding villages (Gendźwiłł et al. 2020).

There are also rational arguments that suggest that the split might not be economically beneficial because the small municipality is not able to invest a large share of its budget into wastewater treatment or a sewage system or is not able to cofinance the project funded by the EU Cohesion Funds. Typically, there are two opposing arguments concerning the economic benefit of secession. On the one hand, the split parts have the possibility to handle their own budget and decide locally where to direct citizens' money. This is labelled 'allocative efficiency' in the academic literature (Ostrom et al. 1961). On the other hand, there is the general argument that a small municipality is unable to bear a large investment project. Either way, citizens must calculate the pros and cons. If the mother municipality does not invest in the part - at least the same amount of money the part would otherwise have received, based on the tax formula and the population - a split would be beneficial. The economic arguments are usually raised by local opinion leaders of both groups. However, both parties try to persuade the public by conducting 'independent' analysis, to realistically and objectively determine ex ante the costs or benefits of a secession.

\section{The role of local elite and citizens' support}

Contextual factors and the actions of the mother municipality are important factors, but it is the role of the local elite that makes a split feasible. First, they raise the issue and mobilize the citizens. The requirements for a successful referendum are quite high, therefore there is a need for local community leaders to have strong organizational skills and competences. A study of Burešová \& Balik (2019) shows that the splits were the second most frequent topic in relation to referendums initiated by committees of citizens. As mentioned above, local leaders are often the initiator of a split, and this was the case in Želechovice

${ }^{2}$ Only a negligible part of income arises from private companies located in a municipality $(1.5 \%)$. See the Ministry of Finance (https://www. financnisprava.cz/cs/dane/danovysystem-cr/rozpoctove-urceni-dani); OECD, Country Report (https://www.oecd.org/ regional/regional-policy/profile-Czech-Republic.pdf) 
in Zlín. Similarly, the economic grievance would not have been enough in the case of Držovice, because other city parts also experienced underinvestment. The difference, though, was that in Držovice, there was a local opinion leader who initiated a successful referendum. She was then elected mayor. A similar story arose in the case of the second initial split in 2006 - that of the Ladná municipality. Furthermore, the local leaders that led campaigns for secession and then became mayors are usually asked to present their experiences, in relation to the process of establishing new municipalities, to citizens of parts that intend to secede. For example, the mayor of Želechovice shared his knowledge with a local activist in the Libhošt' municipality that split from Nový Jičín in 2011. In almost all cases, the local leaders were independent and not members of nationwide political parties. This is because the penetration at local level by nationwide political parties is low, particularly in small rural municipalities (Ryšavý \& Bernard 2013). In larger cities - in the case of Držovice in Prostějov, for example - the local councillors living in split municipalities who are members of nationwide political parties oppose the splits; the initiation comes from independent local leaders.

\section{Reasons for splits: survey and analysis}

In this section, the results of descriptive analysis on why municipalities split are synthesized, and whether there is a common pattern that can generally explain successful splits in the Czech Republic is illustrated. The reasons for splits were predominantly compiled from the interviews with the mayors or local actors of 30 out of the 38 municipalities that have split since 1995. Three general questions were asked: (1) What do you think the main reasons were for the secession of the village? (2) Who was behind or who initiated and organized the secession of the village? (3) How was the initial period after secession? What did the village have to contend with? Were there any problems? ${ }^{3}$ The reasons were also gathered from local newspapers and nationwide journals with regional sections to supplement the survey. For eight of the splits, there is no information in local newspapers and the mayors did not respond to the questions send by email. ${ }^{4}$ Also, supplementary data were gathered, such as the size of the split and mother municipalities and their geographic context.

Table 1 (see below) shows all the municipalities that split between 1995 and 2020. In all the municipalities that responded to the survey in February 2020, all the actors indicated the economic reasons but three of them mentioned historical and cultural factors as being most important. Four respondents indicated that economic and cultural factors were equally important. The results are similar to the only conducted study ${ }^{5}$ on this topic in the Czech Republic (Škrobáčková 2007). In all cases, there was a local initiative of citizens and local leaders (therefore, not shown in the table). They stated the reasons given for the split as their motives, yet personal ambitions might have played a role as well (some of the leaders became mayors afterwards, but not all of them), or even vested interest (school teachers,

\footnotetext{
${ }^{3}$ The survey represents the subjective opinions of the actors; however, the responses were also checked against news articles discussing the split at the time. The collection of data was also complicated by the COVID-19 outbreak.

${ }^{4}$ Out of 38 , I was able to get answers from 30 municipalities. The respondents were former mayors; if they were not in charge during the split that occurred in the past, I asked them to provide the contact details of the former leaders who initiated the referendums or of anyone who remembers the time of the split. The survey represents subjective opinions of the actors; however, the responses were also checked against news articles discussing the split at the time. The collection of data was also complicated by the COVID-19 outbreak.

$577 \%$ of mayors claimed economic reasons, $13 \%$ indicated personal reasons such as the ambitions of local leaders, only $6 \%$ answered that the reasons were historical (former amalgamated municipalities), and $4 \%$ indicated 'other reasons'.
}

as in Krhová and Poličná). In none of the municipalities was the issue raised by the political opposition because political parties were non-existent; they were not present in small municipalities (Kostelecký 2007; Ryšavý \& Bernard 2013). In large cities, parliamentary or local parties govern the whole city, and their support is not usually concentrated on city parts.

Out of 38 secessions, 28 occurred in parts that were geographically distant to the 'natural capital'6; in ten cases, the parts were adjacent to mother municipalities (cities), thus forming one urban area. Regarding the size of a future split municipality, smaller parts generally separate from larger mother towns. Furthermore, small municipalities are hardly able to elect their deputies onto the municipal council under the PR electoral system with a single municipal district, especially in larger towns; thus, they are not able to influence the municipal budget. This is a dominant pattern, as only five splits occurred between two municipalities of virtually the same size. All the other 34 splits occurred involving significantly smaller municipalities. Although cultural factors were the dominant explanation of municipal splits in the first two years of democratic transitions (Bernard \& Kostelecký 2010), there are only a few cases after 1995 of municipal splits that were solely driven by cultural and historical factors. Although there are still hundreds of historical municipal parts that are part of the larger mother municipality that did not secede during the first stage of transformation, they have not seceded in recent times, which suggests that the perceived local identity is weak in those historical parts of municipalities. Cultural identity currently seems to play a secondary role in times of rather consolidated municipal structures. Figure 2 summarizes the reasons listed in Table 1.

While the splits before 2000 were not regarded as very controversial, the splits in 2006 gained nationwide media coverage, due in part to the new Act. The secessionists were quite big municipalities with a population of over a thousand inhabitants. Whereas before 2006 the splits were driven by cultural factors too, the splits after 2006 were driven by the fact that the central municipality had underinvested in municipal parts. The mistreatment of parts is also frequent in the statutory cities ${ }^{7}$ that did not opt for subdivision of their parts into sub-municipal town halls (see Lysek 2018). The city parts remained a blind spot for city councillors. The most famous case was Držovice, part of the statutory city Prostějov.

In some cases, the reasons for the split resulted from plans made by the central municipality to limit services in its city parts. In two parts of Valašské Meziřičí, the city councillors decided to close the grammar school, which triggered the protest of the citizens. Although the councillors backed off and promised greater transparency in the negotiations and offered representatives of the settlement committee to participate in the city council meeting, the citizens in both parts voted to 'exit'. The closure of grammar schools was also the reason for the first secession after 2000 of Ladná from the city of Břeclav, and of Chvojno from the Libouchec municipality in 1998, and Těchlovice from the statutory city of Děćin in 1997. Crucial in the Czech context, another example of the mistreatment of municipal parts was in Kujavy, where the mother municipality Fulnek closed a school and sold the building where the local pub with its dance hall was located. In small towns, local pubs with halls are places where citizens meet and where cultural events take place. Interestingly, two municipalities did not feel underinvested in or exploited,

\footnotetext{
${ }^{6}$ The maps of the location and geographic context of municipal splits can be requested by email. Distant municipalities are treated as ones that are not connected by a built-up area to the mother municipality.

${ }^{7}$ The 27 largest urban municipalities listed in the Municipal Act with a special status. Statutory cities can establish sub-municipal units in their parts with their own council and board.
} 
MISCELLANEA GEOGRAPHICA - REGIONAL STUDIES ON DEVELOPMENT

Vol. 25 • No. 1 • 2021 • pp. 18-27 • ISSN: 2084-6118 • DOI: 10.2478/mgrsd-2020-0042

Table 1. Split municipalities 1995-2020

\begin{tabular}{|c|c|c|c|c|c|c|c|c|}
\hline Region & $\begin{array}{c}\text { New } \\
\text { municipality }\end{array}$ & $\begin{array}{c}\text { Population } \\
\text { (new) }\end{array}$ & $\begin{array}{l}\text { Municipality } \\
\text { (old) }\end{array}$ & $\begin{array}{l}\text { Population } \\
\text { (old) }\end{array}$ & Year & $\begin{array}{l}\text { Population } \\
\text { ratio in \% }\end{array}$ & $\begin{array}{c}\text { Geographical } \\
\text { context }\end{array}$ & Reason \\
\hline Zlínský & Krhová & 1998 & $\begin{array}{l}\text { Valašské } \\
\text { Meziříčí }\end{array}$ & 22926 & 2013 & 8.0 & $\begin{array}{l}\text { integral part of } \\
\text { the city }\end{array}$ & $\begin{array}{l}\text { School } \\
\text { closure }\end{array}$ \\
\hline Zlínský & Poličná & 1699 & $\begin{array}{l}\text { Valašské } \\
\text { Meziříčí }\end{array}$ & 22926 & 2013 & 6.9 & $\begin{array}{l}\text { integral part of } \\
\text { the city }\end{array}$ & $\begin{array}{l}\text { School } \\
\text { closure }\end{array}$ \\
\hline Moravskoslezský & Libhošt' & 1510 & Nový Jičín & 23896 & 2011 & 5.9 & detached & $\begin{array}{c}\text { Own } \\
\text { budget and } \\
\text { responsibility, } \\
\text { cultural } \\
\text { identity }\end{array}$ \\
\hline Olomoucký & $\begin{array}{l}\text { Petrov nad } \\
\text { Desnou }\end{array}$ & 1173 & Sobotín & 1243 & 2010 & 48.6 & detached & $\begin{array}{c}\text { Own } \\
\text { budget and } \\
\text { responsibility }\end{array}$ \\
\hline Zlínský & $\begin{array}{l}\text { Želechovice } \\
\text { nad Dřevnicí }\end{array}$ & 1926 & Zlín & 75714 & 2009 & 2.5 & $\begin{array}{l}\text { integral part of } \\
\text { the city }\end{array}$ & $\begin{array}{c}\text { Sense of } \\
\text { being used } \\
\text { (exploited) or } \\
\text { colonized }\end{array}$ \\
\hline Jihomoravský & Ladná & 1196 & Břeclav & 25652 & 2006 & 4.5 & detached & $\begin{array}{l}\text { School } \\
\text { closure }\end{array}$ \\
\hline Olomoucký & Držovice & 1251 & Prostějov & 47058 & 2006 & 2.6 & $\begin{array}{l}\text { integral part of } \\
\text { the city }\end{array}$ & $\begin{array}{c}\text { Sense of } \\
\text { being used } \\
\text { (exploited) or } \\
\text { colonized }\end{array}$ \\
\hline Olomoucký & $\begin{array}{l}\text { Pavlovice u } \\
\text { Kojetína }\end{array}$ & 314 & Mořice & 483 & 2001 & 39.4 & detached & $\begin{array}{c}\text { Sense of } \\
\text { being used } \\
\text { (exploited) or } \\
\text { colonized }\end{array}$ \\
\hline Olomoucký & $\begin{array}{l}\text { Kobylá nad } \\
\text { Vidnavkou }\end{array}$ & 502 & Žulová & 1375 & 2001 & 26.7 & detached & $\begin{array}{l}\text { Cultural } \\
\text { identity }\end{array}$ \\
\hline Moravskoslezský & Písečná & 805 & Jablunkov & 5919 & 2001 & 12.0 & $\begin{array}{l}\text { integral part of } \\
\text { the city }\end{array}$ & $\begin{array}{c}\text { Own } \\
\text { budget and } \\
\text { responsibility }\end{array}$ \\
\hline Zlínský & Lukoveček & 364 & Fryšták & 3480 & 2001 & 9.5 & detached & $\begin{array}{l}\text { Cultural } \\
\text { identity }\end{array}$ \\
\hline Zlínský & $\begin{array}{c}\text { Bohuslavice } \\
\text { nad Vláří }\end{array}$ & 405 & Slavičín & 7194 & 2001 & 5.3 & detached & $\begin{array}{c}\text { Own } \\
\text { budget and } \\
\text { responsibility }\end{array}$ \\
\hline Plzeňský & Sytno & 301 & Stříbro & 7883 & 2001 & 3.7 & detached & (UNKNOWN) \\
\hline Zlínský & Šelešovice & 317 & Kroměříž & 29394 & 2001 & 1.1 & detached & (UNKNOWN) \\
\hline Zlínský & Ostrata & 353 & Zlín & 81489 & 2001 & 0.4 & detached & (UNKNOWN) \\
\hline Středočeský & Skorkov & 365 & Sojovice & 416 & 2000 & 46.7 & detached & $\begin{array}{c}\text { Richer } \\
\text { and larger } \\
\text { municipality } \\
\text { split }\end{array}$ \\
\hline Karlovarský & Pila & 428 & Kolová & 549 & 2000 & 43.8 & detached & $\begin{array}{c}\text { Own } \\
\text { budget and } \\
\text { responsibility, } \\
\text { cultural } \\
\text { identity }\end{array}$ \\
\hline
\end{tabular}


Continued Table 1. Split municipalities 1995-2020

\begin{tabular}{|c|c|c|c|c|c|c|c|c|}
\hline Region & $\begin{array}{c}\text { New } \\
\text { municipality }\end{array}$ & $\begin{array}{c}\text { Population } \\
\text { (new) }\end{array}$ & $\begin{array}{l}\text { Municipality } \\
\text { (old) }\end{array}$ & $\begin{array}{l}\text { Population } \\
\text { (old) }\end{array}$ & Year & $\begin{array}{c}\text { Population } \\
\text { ratio in } \%\end{array}$ & $\begin{array}{c}\text { Geographical } \\
\text { context }\end{array}$ & Reason \\
\hline Olomoucký & Jezernice & 678 & $\begin{array}{l}\text { Lipník nad } \\
\text { Bečvou }\end{array}$ & 8616 & 2000 & 7.3 & detached & $\begin{array}{l}\text { Own } \\
\text { budget and } \\
\text { responsibility, } \\
\text { cultural } \\
\text { identity }\end{array}$ \\
\hline Zlínský & Rokytnice & 572 & Slavičín & 7655 & 2000 & 7.0 & detached & $\begin{array}{l}\text { Sense of } \\
\text { being used } \\
\text { (exploited) or } \\
\text { colonized }\end{array}$ \\
\hline Jihomoravský & Mouřínov & 463 & Bučovice & 6346 & 2000 & 6.8 & detached & (UNKNOWN) \\
\hline Moravskoslezský & Ropice & 1346 & Třinec & 39147 & 2000 & 3.3 & $\begin{array}{l}\text { integral part of } \\
\text { the city }\end{array}$ & $\begin{array}{l}\text { Sense of } \\
\text { being used } \\
\text { (exploited) or } \\
\text { colonized }\end{array}$ \\
\hline Jihomoravský & Spešov & 584 & Blansko & 21264 & 2000 & 2.7 & $\begin{array}{l}\text { integral part of } \\
\text { the city }\end{array}$ & $\begin{array}{l}\text { School } \\
\text { closure }\end{array}$ \\
\hline Pardubický & $\begin{array}{c}\text { Rabštejnská } \\
\text { Lhota }\end{array}$ & 579 & Sobětuchy & 539 & 1999 & 51.8 & detached & (UNKNOWN) \\
\hline Moravskoslezský & Bravantice & 785 & Bílovec & 7546 & 1999 & 9.4 & detached & (UNKNOWN) \\
\hline Zlínský & Petrůvka & 364 & Slavičín & 8224 & 1999 & 4.2 & detached & $\begin{array}{l}\text { Own } \\
\text { budget and } \\
\text { responsibility, } \\
\text { cultural } \\
\text { identity }\end{array}$ \\
\hline Zlínský & $\begin{array}{l}\text { Lhota u } \\
\text { Vsetína }\end{array}$ & 712 & Vsetín & 29915 & 1999 & 2.3 & detached & (UNKNOWN) \\
\hline Moravskoslezský & Nové Sedlice & 449 & Štítina & 1179 & 1998 & 27.6 & detached & $\begin{array}{l}\text { Cultural } \\
\text { identity }\end{array}$ \\
\hline Ústecký & $\begin{array}{l}\text { Velké } \\
\text { Chvojno }\end{array}$ & 655 & Libouchec & 1734 & 1998 & 27.4 & detached & $\begin{array}{l}\text { School } \\
\text { closure }\end{array}$ \\
\hline Moravskoslezský & Kujavy & 561 & Fulnek & 6055 & 1998 & 8.5 & detached & $\begin{array}{l}\text { School } \\
\text { closure }\end{array}$ \\
\hline Vysočina & $\begin{array}{l}\text { Nová Ves u } \\
\text { Světlé }\end{array}$ & 430 & $\begin{array}{l}\text { Světlá nad } \\
\text { Sázavou }\end{array}$ & 7222 & 1998 & 5.6 & detached & (UNKNOWN) \\
\hline Jihomoravský & Kurdějov & 331 & Hustopeče & 5872 & 1998 & 5.3 & detached & $\begin{array}{l}\text { Own } \\
\text { budget and } \\
\text { responsibility }\end{array}$ \\
\hline Moravskoslezský & Chotěbuz & 988 & Český Těšín & 27116 & 1998 & 3.5 & $\begin{array}{l}\text { integral part of } \\
\text { the city }\end{array}$ & $\begin{array}{l}\text { Own } \\
\text { budget and } \\
\text { responsibility }\end{array}$ \\
\hline Pardubický & Semanín & 521 & $\begin{array}{l}\text { Česká } \\
\text { Třebová }\end{array}$ & 17167 & 1998 & 2.9 & detached & $\begin{array}{l}\text { Sense of } \\
\text { being used } \\
\text { (exploited) or } \\
\text { colonized }\end{array}$ \\
\hline Jihomoravský & $\begin{array}{l}\text { Suchohrdly } \\
\text { (u Znojma) }\end{array}$ & 1007 & Znojmo & 36217 & 1998 & 2.7 & $\begin{array}{l}\text { integral part of } \\
\text { the city }\end{array}$ & $\begin{array}{l}\text { Sense of } \\
\text { being used } \\
\text { (exploited) or } \\
\text { colonized }\end{array}$ \\
\hline
\end{tabular}


MISCELLANEA GEOGRAPHICA - REGIONAL STUDIES ON DEVELOPMENT

Vol. $25 \cdot$ No. $1 \cdot 2021 \cdot$ pp. 18-27 • ISSN: 2084-6118 • DOI: 10.2478/mgrsd-2020-0042

Table 1. Split municipalities 1995-2020

\begin{tabular}{|c|c|c|c|c|c|c|c|c|}
\hline Region & $\begin{array}{c}\mathrm{New} \\
\text { municipality }\end{array}$ & $\begin{array}{c}\text { Population } \\
\text { (new) }\end{array}$ & $\begin{array}{l}\text { Municipality } \\
\text { (old) }\end{array}$ & $\begin{array}{l}\text { Population } \\
\text { (old) }\end{array}$ & Year & $\begin{array}{l}\text { Population } \\
\text { ratio in } \%\end{array}$ & $\begin{array}{c}\text { Geographical } \\
\text { context }\end{array}$ & Reason \\
\hline Ústecký & Těchlovice & 434 & Děčín & 53427 & 1997 & 0.8 & detached & $\begin{array}{l}\text { School } \\
\text { closure }\end{array}$ \\
\hline Pardubický & Otradov & 312 & Krouna & 1384 & 1996 & 18.4 & detached & $\begin{array}{c}\text { Sense of } \\
\text { being used } \\
\text { (exploited) or } \\
\text { colonized }\end{array}$ \\
\hline Olomoucký & Mrsklesy & 499 & Velká Bystřice & 2877 & 1996 & 14.8 & detached & $\begin{array}{c}\text { Sense of } \\
\text { being used } \\
\text { (exploited) or } \\
\text { colonized }\end{array}$ \\
\hline Moravskoslezský & Bítov & 416 & Bílovec & 8312 & 1996 & 4.8 & detached & $\begin{array}{c}\text { Bypassing } \\
\text { the planned } \\
\text { gas pipelines }\end{array}$ \\
\hline
\end{tabular}

Source: The Czech Statistical Office (https://www.czso.cz/csu/rso/prehled_zmen_rso) and own survey. All the data and further information can be requested by email from the author.

Note: The population ratio is calculated as 'population (new)' divided by the sum of 'population (new)' and 'population (old)', converted to a percentage.

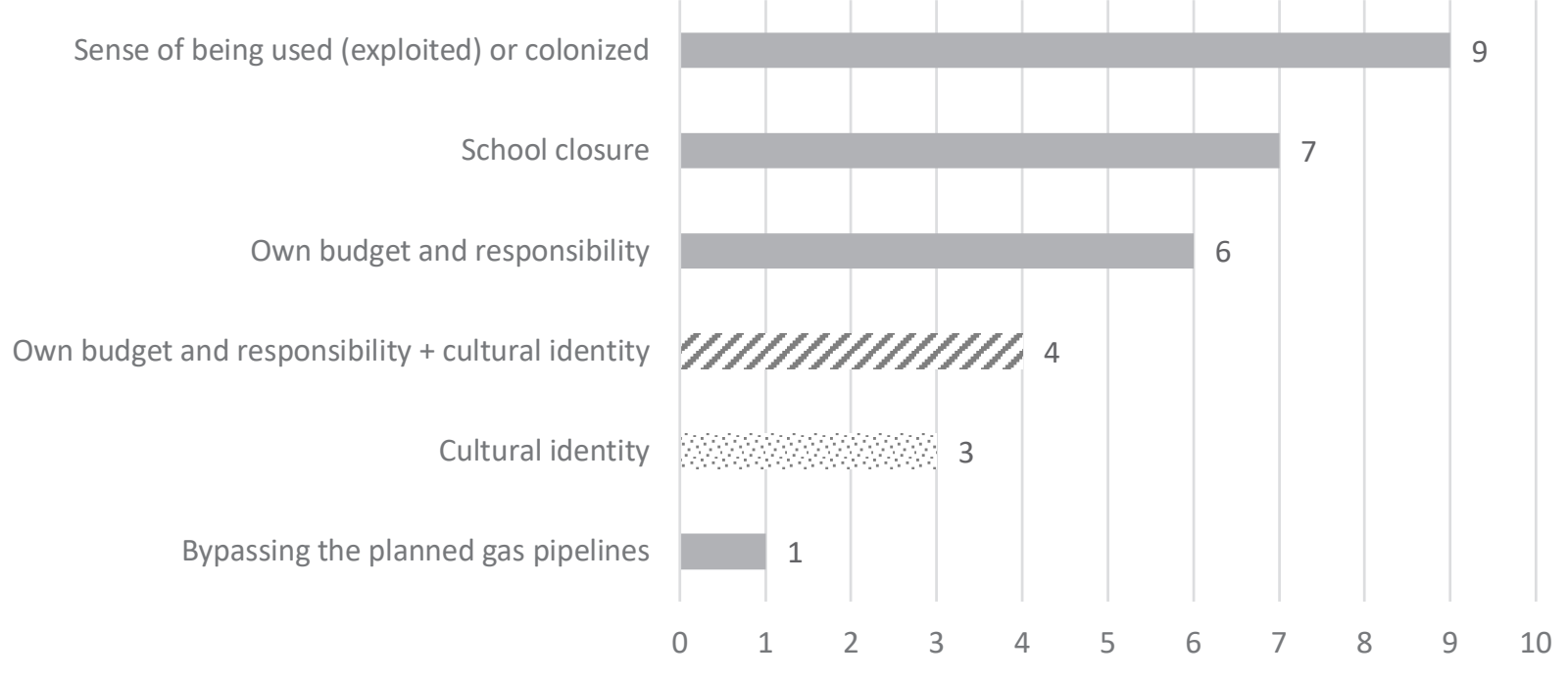

Figure 2. Reasons for split - based on interviews and survey responses (municipalities)

Note: Response rate 30 (38). Grey fill colour indicates economic reasons. Dot fill indicates only cultural factors as dominant. Four municipalities indicated that both economic and cultural factors were equally important.

Source: Own collection of survey data.

because the mother municipality objectively invested in these parts (e.g. Libhošt' and Nový Jičín), yet they decided to have their own budget for both cultural and economic reasons, which are complementary and not exclusive, because culturally self-aware municipalities want to make decisions on their own.

Regionally, splits have occurred disproportionately in the Zlín region (10 splits), Moravian-Silesian region (8), Olomouc region (6) and South-Moravian region (5). These four regions are all located in the eastern part of the country, historically called Moravia, while in the western (Bohemian) part, splits have been rare despite the fact that the population is larger (6.2 compared to 3.9 million). Both parts have small as well as large regions so the number is not affected by population size. Furthermore, the municipal structure is not as fragmented in Moravia. Moravian municipalities are comparatively larger in population size than Bohemian ones (Bernard \& Kostelecký 2010) and they also generally perceive themselves as having a strong cultural and identity (Perlín et al. 2010). They score high on social capital and participation (Pileček \& Jančák 2010). ${ }^{8}$ The traditional culture and bigger size of

${ }^{8}$ Furthermore, the media coverage of Moravian splits was higher while it was difficult to get any information from local media about splits in Bohemian regions. Municipal splits are thus quite freely discussed in Moravia. 
municipalities can explain why splits occurred predominantly in Moravian regions.

\section{Unsuccessful splits}

The picture would not be complete without mentioning that there were several unsuccessful attempts for municipal divorce. In several municipalities, ${ }^{9}$ the split was not approved by citizens. In municipal parts of mother municipalities (in parentheses), citizens from Kostelec u Zlína (Zlín), Kokonín (Jablonec nad Nisou), Jarošov (Uherské Hradiště), Lubina (Koprivnice) and Skalice (Frýdek-Mistek) voted against the motion. Yet in Dolni Heršpice - Přízřenice (Brno), despite $58 \%$ of citizens of that city part voting for a divorce, the referendum was not valid because the group favouring secession formed only $41 \%$ of all the registered voters, as per the Municipal Act. Sometimes, the referendum served as a way to raise citizens' voices that felt neglected and abandoned by the central municipal council. Why did those referendums fail? In all cases, the mother municipality tried to communicate to them that it took care of its parts and that it invested in the infrastructure. Sometimes, it established a neighbourhood committee (a kind of a sub-municipal council, yet with no or limited power) that could consult or even decide on investments. The role of a leader is crucial - the mayor of the mother municipality or councillors - and in most failed cases, the mayor directly communicated door-to-door with citizens of the municipal part. If the mayors and councillors managed to communicate with the citizens and if they showed they were investing in the municipal parts, citizens usually rejected the proposal for a split. This was the case of Jarošov (23\% supported the split) and Lubina (only $16 \%$ supported the split). The failure in Lubina was also due to the mayor of Koprivnice coming from this part, as well as four other councillors. This part was actually overrepresented. Conversely, in several successful splits, the local actors of the mother municipality generally acknowledged that they failed to communicate with citizens living in those parts that had split.

\section{Discussion: consequences of splits}

Based on the limited number of cases it is hard to infer the general impact of splits on the functioning of a municipality or its socio-economic development. The only study conducted in the Czech Republic (Bernard \& Kostelecký 2010) found that in the category of municipalities with fewer than 1,000 inhabitants there was no difference in the socio-economic development between settlements that have their own local government and communities that form a part of a bigger municipality and do not dispose therefore of their own local government. However, there was a tendency that showed that having an administrative status, as opposed to being just a municipal part, positively correlates with socio-economic development in the group of larger municipalities and their parts (settlements with populations of more than 1,000). The study of Bernard \& Kostelecky $(2010)$ thus supports the claim that larger settlements, without their own local government, should split from the mother municipality. Indeed, the split municipalities subjectively claim they are better off after the secession. However, the effect of a split on efficiency and effectiveness is unclear. On the one hand, the economy of scale assumption applies because the newly established municipality must hire officials to the municipal office and other public service positions, including elected members of local council. The costs are fixed and the further fragmentation inherently lowers efficiency, especially in terms of measures such as per capita spending on local administration or the percentage share of spending on local administration compared to total expenditure (Sharpe 1995; Gimenez \& Prior 2007; Swianiewicz \& Łukomska 2019; Gendźwiłł et al. 2020). Moreover, in the Czech context, a simple equation generally applies regarding tax revenues: the original municipality, before the secession of its part, receives more than the two successor municipalities after the separation. On the other hand, the 'closeness' to citizens means they can better decide what the investment needs are. Furthermore, some clear benefits can hardly be economized, such as an increase in cultural and associational life in a municipality.

The splits are commonly perceived as disadvantageous for the capital municipality. The current mayor of the Slavičín municipality, Tomáš Chmela, refers to the year 2000 as the year of 'Africa 1960 '. ${ }^{10}$ During a short period, it lost three of its parts and $13 \%$ of its population. Because of that, the city of Slavičín lost its status as a regional centre, and in the administrative reform of 2003 (see Illner 2011, p.511), it was divided into two administrative districts (so-called municipalities with delegated power). ${ }^{11}$ If it had not lost its parts, it would have not lost its importance and administrative status. Regarding the effectiveness debate, the separated municipalities do not form one single microregion but are divided into three. The cooperation of split municipalities is crucial in this regard. Unfortunately, most of the newly split municipalities are not involved in microregion or Local Action Groups as forms of inter-municipal cooperation (IMC) activities.

Frequently, the initiators of splits argue that citizens do not have a means for effective democratic participation. A study from Poland (Swianiewicz et al. 2018) demonstrates that the electoral turnout in municipalities that initiated a referendum did indeed increase, but the electoral competition simultaneously decreased. At least regarding the turnout, the results are similar in the Czech context. Comparing the turnout in elections preceding the split and following the split (difference-in-differences design of the paired electoral precinct in new and old municipalities), the turnout increases in new municipalities by approximately $24 \%$ in the following election. However, the split municipalities do not differ from their independent counterparts as in all the municipal elections after 2010 the difference in turnout between split municipalities and controls (based on the matching method algorithm) is not significant and substantial. The results also show that in the split municipalities, the number of candidates is the same as in similar sized municipalities with similar sociodemographic conditions. The same trend, as identified globally on Czech municipal election data by Ryšavý \& Bernard (2013), shows that in split municipalities with small populations the number of candidates is lower than in bigger ones (correlation between size and number of candidates per seats is 0.47 using the Spearman rank coefficient). Therefore, the split only has a temporal effect on electoral turnout and in time the split municipalities do not differ to other municipalities.

\section{Conclusion and policy implications}

Before the reform of the municipal law setting the requirement of 1,000 inhabitants from newly seceded municipalities, the splits were driven by perceived local identity and the historical memory of being a former independent municipality. Those former municipalities that wanted to split from the amalgamated centre did it after the regime transition, and after 1992 with a referendum and the consent of its citizens. Yet after 1995, the splits were predominantly driven by economic factors, be it objective underinvestment or perceived grievance that the mother municipality did not take care of its fringe parts. Economic or cultural factors did not operate independently but in conjunction

\footnotetext{
${ }^{10}$ Interview with Tomáš Chmela, the mayor of Slavičín and deputy director of the Associations of Local Municipalities (SMS ČR).

${ }^{11}$ There are 205 municipalities (ORPs) that are endowed with state delegated powers. They are responsible for conducting state delegated tasks within their district. These municipalities serve virtually as an intermediary tier between the region and the smallest municipalities (see IIIner 2011).
} 
with political factors. They gave a structure opportunity for local (independent) leaders. In all cases, the mother municipality failed to communicate with the initiator and overwhelmingly lost the referendums. However, if the central municipality invested in its parts and its political leaders communicated with the citizens, the referendum failed.

What are the lessons learned? While there are clear benefits of splits such as increased political participation, it may be claimed that smaller split municipalities are unable to bear large investment projects due to economies of scale. As a result of the population threshold since 2001 , the splits typically occur in local parts of larger cities. Just recently, in 2009, a municipality Želechovice nad Drevnici split from the statutory city Zlín. A local activist stated that their first demand during the negotiations was that the statutory city opt for decentralization and establish the sub-municipal government in its separationist part. ${ }^{12}$ Although the statutory cities (the 27 largest urban municipalities with special status listed in the Municipal Act; see Lysek 2018) have the right to establish sub-municipal units, most of them did not opt to do so. This example is just an illustration because it shows the general pattern, whereby other statutory cities failed in dealing with their parts and, as a consequence, lost them. The policy implication of this study is that the statutory cities that have remained centralized and that have already lost their parts or are facing separatist tendencies should consider the creation of "little town

${ }^{12}$ Michal Špendlík, who became a mayor. Email communication. halls' in their city parts. This would possibly prevent secessions. Establishing 'little town halls' means securing local participation and economy of scale at the same time. Possibly, this could lead to a voluntary return of the lost parts. ${ }^{13}$ If the municipality is a small town, it is advisable to establish a neighbourhood council and to allocate the budget the municipal part would otherwise get if it were an independent municipality. Due to the shared tax formula, losing its parts is always disadvantageous for the mother municipality. The mother municipality must not fail to communicate with its parts; otherwise it is destined to lose them.

\section{Acknowledgments}

This work was supported by the Czech Science Foundation (Grantová agentura České republiky) under grant Political competition and local democracy in comparative perspective (GA20-02098S).

\section{ORCID}

Jakub Lysek (1D https://orcid.org/0000-0003-3583-9917

\section{References}

Bernard, J \& Kostelecký, T 2010, 'Části obcí s vlastn samosprávou a bez ní: Vliv administrativního statusu části obce na její rozvoj' ['Parts of municipalities with and without self-government: Influence of administrative status of part of municipality on its development'], Acta politologica, vol 2, no 3, pp. 46-61.

Brink, A 2004, 'The break-up of municipalities: Voting behavior in local referenda', Economics of Governance, vol. 5, no. 2, pp. 119-135.

Burešová, B \& Balík, S 2019, 'Kdo jsou iniciátoři místních referend v ČR?' ['Who are the initiators of local referendums in the Czech Republic?'], Acta Politologica, vol. 11, no. 2, pp. 18-38.

Campbell, A \& Coulson, A 2008, Local Government in Central and Eastern Europe: The Rebirth of Local Democracy, Routledge, London.

Dollery, B, Kortt, M \& Grant, B 2011, 'A normative model for local government de-amalgamation in Australia', Australian Journal of Political Science, vol. 46, no. 4, pp. 601-615.

Erlingsson, GO 2005, 'Modelling secessions from municipalities', Scandinavian Political Studies, vol. 28, no. 2, pp. 141-159.

Gimenez, VM \& Prior, D 2007, 'Long- and short-term efficiency frontier evaluation: Evidence from Spanish Local Governments', Fiscal Studies, vol. 28, no. 1, pp. 121-139.

Gendźwiłł, A, Kurniewicz, A \& Swianiewicz, P 2020, 'The impact of municipal territorial reforms on economic performance of local governments: systematic review of quasi-experimental studies', Space and Polity. Available from: <https://doi.org/1 0.1080/13562576.2020.1747420>. [8 February 2020].

Hudečková, H \& Pitterling, M 2009, 'Integration and independence in the perspective of rural municipalities', Agricultural Economics, vol. 55, no. 12, pp: 596-604.

Illner, M 1999, 'Territorial government in the Czech Republic' in Decentralization and Transition in the Visegrad, Basingstoke, ed. EJ Kirchner, Palgrave Macmillan, London, pp. 80-101.
Illner, M 2003, 'The Czech Republic 1990-2001: Successful reform at the municipal level and a difficult birth of the intermediary government' in Local Democracy in PostCommunist Europe, eds H Baldersheim, M Illner \& H Wollmann, Opladen, Leske \& Budrich, pp. 61-90.

Illner, M 2006, 'Velikost obcí, efektivita jejich správy a lokální demokracie' ['Size of municipalities, efficiency of their administration and local democracy'] in Autonomie a spolupráce: důsledky ustavení obecního zrízeni v roce 1990, eds Z Vajdová, D Čermák \& M IIIner, Sociologické studie, vol. 06/2, Sociologický Ústav AV ČR, v.v.i., Praha, pp. 15-26.

Illner, M 2011, 'The Czech Republic' in The Oxford handbook of local and regional democracy in Europe, eds J Loughlin, $\mathrm{F}$ Hendriks \& A Lidström, Oxford University Press, Oxford, pp. 505-527.

Kostelecký, T 2007, 'Political parties and their role in local politics in the post-communist Czech Republic' in Local government reforms in countries in transition, eds $\mathrm{F}$ Lazin, $M$ Evans, V Hoffmann-Martinot \& H Wollmann, Lexington Books, Lanham-Boulder-New York-Toronto-Plymouth, pp. 121-139.

Lima, RCA \& Neto, RMS 2018, 'Secession of municipalities and economies of scale: evidence from Brazil', Journal of Regional Science, vol. 58 , no. 1 , pp. 159-180.

Lysek, J 2018, 'The "Little Town-Halls" in the Czech Republic: An unexploited potential of functional decentralization' in SubMunicipal Governance in Europe: Decentralization Beyond the Municipal Tier, eds NK Hlepas, N Kersting, S Kuhlmann, $P$ Swianiewicz \& F Teles, Palgrave Macmillan, Basingstoke, pp. 41-68.

Musil, J 2001, 'Vývoj a plánování měst ve střední Evropě v období komunistických režimů' ['Urban development and planning in Central Europe during the communist regimes'], Sociologický časopis, vol. 37, no. 3, pp. 275-296. 
OECD, Country Report. Available from: <https://www.oecd.org/ regional/regional-policy/profile-Czech-Republic.pdf>. February 2020].

Ostrom, V, Tiebout, C \& Warren, R 1961, 'The organization of government in metropolitan areas: A theoretical inquiry', American Political Science Review, vol. 55, no. 4, pp. 831-42.

Perlín, R, Kučerová, S \& Kučera, Z 2010, 'A typology of rural ppace in Czechia according to its potential for development', Geografie, vol. 115, no. 2, pp. 161-187.

Pileček, J \& Jančák, V 2010, 'Can social capital be measured? An analysis of territorial differences among the districts of Czechia', Geografie, vol. 115, no. 1, pp. 78-95.

Ryšavý, D \& Bernard, J 2013, 'Size and local democracy: The case of Czech Municipal Representatives', Local Government Studies, vol. 39, no. 6, pp. 833-852.

Sharpe, LJ 1995, 'Local government: Size, efficiency and citizen participation' in Local and Regional Authorities in Europe, ed. LJ Sharpe, Council of Europe, no. 56, Strasbourg, pp. 9-59.

Swianiewicz, P, Gendźwiłt, A \& Łukomska, J 2018, 'Inicjatorzy i opuszczeni: demokracja lokalna po gminnych rozwodach' ['Initiators and abandoned: local democracy after communal divorces'], Prace Geograficzne, vol. 154, pp. 7-33.

Swianiewicz, P \& Łukomska, J 2019, 'Is small beautiful? The quasi-experimental analysis of the impact of territorial fragmentation on costs in Polish local governments', Urban Affairs Review, vol. 55, no. 3, pp. 832-855.

Swianiewicz, P 2021, 'From post-communist democratic laissezfaire to prevention of territorial fragmentation: tightening the rules of municipal splits in Central and Eastern Europe after 1990', Miscellanea Geographica - Regional Studies on Development, vol. 25, no. 1, pp. 5-17.

Škrobáčková, H 2007, Reasons and consequences of the creation of new municipality in CR, Master thesis, Masaryk University, Brno.

Tanguay, GA \& Wihry, DF 2008, 'Voters' preferences regarding municipal consolidation: evidence from the Quebec demerger referenda', Journal of Urban Affairs, vol. 30, no. 3, pp. 325-345.

The Czech Statistical Office. Available from: <https://www.czso. cz/csu/rso/prehled_zmen_rso>. [8 February 2020].

The Ministry of Finance. Available from: <https://www. financnisprava.cz/cs/dane/danovy-system-cr/rozpoctoveurceni-dani>. [8 February 2020].

The Local Finance Act 243/2000. Available from: <https://www. mvcr.cz/mvcren/file/act-on-municipalities-2000-pdf.aspx>. [8 February 2020].

Vajdová, Z, Čermák, D \& IIIner, M 2006, Autonomie a spolupráce: důsledky ustavení obecního zrízení v roce 1990 [Autonomy and cooperation: consequences of the establishment of the municipal establishment in 1990], Sociologický ústav AV ČR, Praha. 